\title{
Aspartate transport by the Dct system in Rhizobium leguminosarum negatively affects nitrogen-regulated operons
}

\author{
Colm J. Reid, † David L. Walshaw and Philip S. Poole \\ Author for correspondence: Philip S. Poole. Tel: +44 1734 318895. Fax: +441734 316671. \\ c-mail: p.s.poole@rcading.ac.uk
}

School of Animal and Microbial Sciences, University of Reading, Whiteknights, PO Box 228, Reading RG6 2AJ, UK
Amino acid uptake by the general amino acid permease (Aap) of Rhizobium leguminosarum strain $\mathbf{3 8 4 1}$ was severely reduced by the presence of aspartate in the growth medium when glucose was the carbon source. The reduction in transport by the Aap appeared to be caused by inhibition of uptake and not by transcriptional repression. However, as measured with lacZ fusions, the Ntrregulated gene $g / n / I$ was repressed by aspartate. The negative regulatory effect on both the Aap and gin/I was prevented by mutation of any component of the dicarboxylate transport (Dct) system or by the inclusion of a $\mathrm{C}_{4}{ }^{-}$ dicarboxylate in the growth medium, including the non-metabolizable analogue 2-methylsuccinate. As measured by total uptake and with a dctA-lacz fusion, aspartate was an efficient inducer of the Dct system, but slightly less so than succinate alone or succinate and aspartate together. Thus, aspartate does not cause overexpression of DctA leading to improper regulation of other operons. Transport measurements reveaied that the Dct system has an apparent $K_{\mathrm{m}}$ for succinate of $5 \mu \mathrm{M}$ and an apparent $K_{\mathrm{i}}$ for aspartate inhibition of succinate uptake of $5 \mathrm{mM}$. These data imply that the Dct-mediated accumulation of aspartate causes an unregulated build-up of aspartate or a metabolic product of it in the cell. This accumulation of aspartate is prevented either by mutation of the dct system or by the presence of a higher affinity substrate that will reduce access of aspartate to the carrier protein. Elevation or disruption of the intracellular aspartate pool is predicted to disrupt $\mathbf{N}$ regulated operons and nitrogen fixation.

Keywords: aspartate transport, dct, $n t r, a a p$, amino acid transport

\section{INTRODUCTION}

Nutrient exchange in legume nodules is dependent upon the micro-symbiont, or bacteroid, reducing $\mathrm{N}_{2}$ to ammonia in return for a carbon source from the plant. Most studies indicate that the carbon source provided by the plant for use by the bacteroid is a $\mathrm{C}_{4}$-dicarboxylic acid, either L-malate, succinate or fumarate. This conclusion is suppotted by the ability of $\mathrm{C}_{4}$-dicarboxylates to allow high rates of respiration in isolated bacteroids (Glenn \& Dilworth, 1981). Furthermore, mutations in either malic enzyme or the structural gene for the dicarboxylate transport system $(\operatorname{dct} A)$ abolish nitrogen fixation, while

†Present address: Institute of Molecular Medicine, University of Oxford, John Radcliffe Hospital, Oxford OX3 9DU, UK.

Abbreviation: Dct, dicarboxylate transport. mutations preventing sugar catabolism have no effect (Ronson et al., 1981; Finan et al., 1983; A twas et al., 1985; Glenn et al., 1984; Driscoll \& Finan, 1993). The dependence of nitrogen fixation on the transport and catabolism of dicarboxylates has led to intensive study of the dicarboxylate transport (Dct) system. In Rhizobium leguminosarum and Rbizobium (now Sinorbizobium) meliloti, $\operatorname{dct} A$ codes for the putative dicarboxylate transport protein while $\operatorname{dct} B$ and $d c t D$ code for a two-component sensor and regulator, respectively, transcribed divergently from $\operatorname{dct} A$, which activate transcription of $\operatorname{dct} A$ in response to the presence of dicarboxylates in the environment (Ronson et al., 1984, 1987; Watson, 1990; Jiang et al., 1989; Engelke et al., 1989; Ronson \& Astwood, 1985; Wang et al., 1989). Dicarboxylates are presumably detected by DctB, either by directly binding the substrate itself or via detection of the substratebinding state of DctA. Most models suggest that DctB 
undergoes autophosphorylation and in turn phosphorylates DctD, which binds to the tandem upstream activator sites of det $A$ enabling it to activate transcription (Ronson, 1988; Yarosh et al, 1989; Jording et al., 1992; Ledebur et al., 1990; Ledebur \& Nixon, 1992).

The pattern of nutrient flux in the bacteroid appears to be more complex than a simple oxidation of $\mathrm{C}_{4}$-dicarboxylates. Labelling studies with $\left[{ }^{14} \mathrm{C}\right]$ succinate and ${ }^{14} \mathrm{CO}_{2}$ show that in pea and soybean bacteroids there is a substantial accumulation of glutamate (Salminen \& Streeter, 1987, 1992). Isolated pea bacteroids and symbiosomes, which retain the plant-derived peribacteroid membrane, have been shown to excrete both alanine and aspartate when incubated with a $\mathrm{C}_{4}$-dicarboxylic acid (Appels \& Haaker, 1991; Rosendahl et al., 1992). While all these studies are in agreement that amino acids accumulate and are excreted by pea bacteroids, the significance of this is unclear. At one extreme, it has been proposed that a modified malate-aspartate shuttle is operating, which requires the co-ordinated uptake of glutamate and a $\mathrm{C}_{4}$-dicarboxylic acid, coupled to the excretion of alanine/aspartate and 2-oxoglutarate (Appels \& Haaker, 1991). An alternative explanation is that amino acids are synthesized endogenously by the bacteroid, as a mechanism to remove excess keto acids and possibly $\mathrm{NAD}(\mathrm{P}) \mathrm{H}$. This proposal is supported by the observation that 2-oxoglutarate dehydrogenase is inhibited by a high $\mathrm{NADH} / \mathrm{NAD}^{+}$ratio in bacteroids of Bradyrbizobium japonicum and this is consistent with the observed accumulation of glutamate in soybean and pea bacteroids (Saiminen \& Streeter, 1990). In all these studies it is clear that glutamate, aspartate and alanine play a central role in bacteroid metabolism. Furthermore, it has been shown that a mutation in the gene coding for aspartate amino transferase (at $A$ ) in $R$. meliloti prevents formation of effective nitrogen-fixing bacteroids (Rastogi \& Watson, 1991; Watson \& Rastogi, 1993). This implies that aspartate itself or transamination cycles are essential to effective nitrogen fixation by alfalfa bacteroids.

Given the importance of amino acid metabolism in bacteroids we have recentiy cloned and mutated the highaffinity general amino permease (aap) from $R$. leguminosarum (Walshaw \& Poole, 1996) (EMBL X82596). The aap operon consists of four genes ( $a a p J, Q, M, P$ ), which code for an $A B C$-type transport complex, which is the principal high-affinity uptake system for glutamate and aspartate. This system is unusual in that it transports a broad range of structurally distinct L-amino acids. It also has a powerful exchange activity enabling amino acids from intra- and extra-cellular pools to equilibrate. These properties suggest that this system might be crucial to any processes of amino acid cycling in bacteroids. While examining aspartate utilization, we discovered that the Aap is regulated by the level of this amino acid and we report here the nature of this effect.

\section{METHODS}

Bacterial strains and culture conditions. The strains used ate described in Table 1. Bacteria were grown on either TY (Beringer, 1974) or on acid minimal salts (AMS) medium, which is derived from that of Brown \& Dilworth (1975) with the changes being: phosphate $(0.5 \mathrm{mM}), \mathrm{MgSO}_{4}(2 \mathrm{mM}), \mathrm{CaCl}_{2}$ $(0.17 \mathrm{mM})$ and buffering provided by MOPS $(20 \mathrm{mM}), \mathrm{pH} 7 \cdot 0$. Ali carbon and nitrogen sources were at $10 \mathrm{mM}$. Antibiotics were used at the following concentrations (in $\mu \mathrm{g} \mathrm{ml}^{-1}$ ); kanamycin, 40; streptomycin, 500; tetracycline, 2 (in AMS), 5 (in TY); gentamicin, 20; ampicillin, 50; spectinomycin, 100; unless otherwise stated.

Transport assays. Cells were prepared and transport by the Aap assayed as previously described (Poole et al., 1985), using $4.6 \mathrm{kBq} \mathrm{L}-\left\{\mathrm{U}_{-}{ }^{14} \mathrm{C}\right]$ aspartate $\left(7.81 \mathrm{GBq} \mathrm{mmol}^{-1}\right)$, L- $\left[\mathrm{U}^{1}{ }^{14} \mathrm{C}\right]$ glutamate $\left(9 \cdot 77 \mathrm{GBq} \mathrm{mmol}{ }^{-1}\right)$ or L- $\left[\mathrm{U}^{14}{ }^{14} \mathrm{C}\right]$ alanine $\left(5.7 \mathrm{GBq} \mathrm{mmol}^{-1}\right)$ at a total substrate concentration of $25 \mu \mathrm{M}$. The kinetics of succinate uptake by the Det system were measured using [2,3$\left.{ }^{14} \mathrm{C}\right]$ succinate $\left(0.46 \mathrm{GBq} \mathrm{mmol}^{-1}\right)$ at various total substrate concentrations over one minute time intervals.

DNA and genetic manipulations. Ail routine DNA analysis was done essentially according to Sambrook et al. (1989), Southern blots were performed with an Amersham ECL kit according to the manufacturer's instructions. Conjugations were performed using either Escherichia colis strain $\$ 17-1$ as the donor strain according to Simon et al. (1983) or as triparental matings according to Figurski \& Helinski (1979) with either $E$. coli strains 803 or DH $5 x$ as the donor, and strain 803 containing pRK2013 providing the transfer functions.

Construction of a dctA-lacz fusion. The cosmid pRU3001, which is derived from $\mathrm{R}$. leguminosarum biovar viciae $3841 \mathrm{DNA}$ (Poole et al., 1994), was digested with EcoRI and the dit $A-B$ intergenic region, previously mapped on a $0.9 \mathrm{~kb}$ fragment, was ligated into Bluescript II SK-, yielding pRU16. This was sequenced to confirm it was inserted as required. The EcoRI insert from pRU16 was cloned in the approptiate orientation in the EcoRI site of $\mathrm{pMP} 220$ to obtain a dot $A p-l a c Z$ transcriptional promoter probe, $\mathrm{pRU} 103$.

dct insertion and deletion mutants. These wete constructed using a common scheme. Gene replacement strains were created using the suicide vector pJQ200KS as desctibed by Quand \& Hynes (1993). All the mutants were marked by an $\Omega$ interposon encoding spectinomycin resistance, which contains transcriptional and translational stop signals in all three reading frames at either end, minimizing read-through from endogenous promoters (Ptentki \& Krisch, 1984). The insertions and deletions were generated in Bluescript II SK-, ensuring that the final clones containing the mutated alleie had sufficient flanking DNA ( $>700 \mathrm{bp}$ at each end), for a cross-over event to occur. All these mutated dit alleles were cloned into the suicide vector PJQ200KS.

The starting plasmid for all gene replacements was pRL47, which contains a HindIII fragment from the cosmid pIJ1848 spanning the complete $d t t$ region, cloned in Bluescript II SK-. This was digested with ClaI and religated to form $\mathrm{pRU}$ 150. This was further digested with $X b a \mathrm{I}$ and HindIII, filled-in and religated to remove part of the Bluescript II SK - polylinker, yieiding pRU151, which was used for the construction of all subsequent mutated $d c t$ alleles.

The following plasmids are all pJQ200KS derivatives. Plasmid pRU324 contains an $\Omega$ interposon cloned into the BamHI site of $\operatorname{dct} A$ and is flanked by $1.8 \mathrm{~kb}$ of insert DNA on the $\operatorname{dct} A$ side and $4.2 \mathrm{~kb}$ on the $\operatorname{dct} \mathrm{B}$ side. Plasmid pRU325 contains the complete $d c t$ region with an $\Omega$ interposon cloned into the EcoRI site in $d c t B$ and is flanked by $3.0 \mathrm{~kb}$ of insert DNA on the $\operatorname{dct} A$ side and $3.2 \mathrm{~kb}$ on the $d c t B$ side. Plasmid pRU168 contains $\operatorname{dct} D$ with the internal $123 \mathrm{bp} N r u \mathrm{I}$ fragment deleted. The $\Omega$ interposon was blunt-end-ligated into this site, placing it $895 \mathrm{bp}$ downstream from the start of $d c t D$, and flanked by $0.73 \mathrm{~kb}$ of 
Table 1. Bacterial strains and plasmids used

\begin{tabular}{|c|c|c|}
\hline Strain or plasmid & Relevant characteristics & Reference \\
\hline \multicolumn{3}{|l|}{ R. leguminosarum } \\
\hline 3841 & $\mathrm{Str}^{\mathrm{R}}$ derivative of $\mathrm{R}$. leguminosarum biovar viciat strain 300 & Johnston \& Beringer (1975) \\
\hline RU543 & Strain 3841 aapJ:: Tn5lacZ & Walshaw \& Poole (1996) \\
\hline RU711 & Strain $3841 \Delta d c t D-\Omega, \mathrm{Str}^{\mathrm{R}} \mathrm{Sp}^{\mathrm{R}}$ & This work \\
\hline RU714 & Strain $3841 \Delta d c t A B D-\Omega, \mathrm{Str}^{\mathrm{R}} \mathrm{Sp}^{\mathrm{R}}$ & This work \\
\hline RU727 & Strain 3841 dct $A-\Omega, \mathrm{Str}^{\mathrm{R}} \mathrm{Sp}_{\mathrm{p}}^{\mathrm{R}}$ & This work \\
\hline RU730 & Strain 3841 dctB- $\Omega, \mathrm{Str}^{\mathrm{R}} \mathrm{S}_{\mathrm{p}}^{\mathrm{R}}$ & This work \\
\hline RU865 & Strain $3841 \Delta d c t B D \Omega, \mathrm{Str}^{\mathrm{R}} \mathrm{Sp}^{\mathrm{R}}$ & This work \\
\hline \multicolumn{3}{|l|}{ E. coli } \\
\hline 803 & met gal & Wood (1966) \\
\hline $\mathrm{S} 17-1$ & $\begin{array}{l}\text { pro bsdR recA }[\mathrm{RP} 4-2(\mathrm{Tc}:: \mathrm{Mu})(\mathrm{Km}:: \mathrm{Tn} 7)], \mathrm{RP} 4 \text { integrated into its } \\
\text { chromosome }\end{array}$ & Simon et al. (1983) \\
\hline $\mathrm{DH} 5 \alpha$ & $\begin{array}{l}\text { supE44 DlacU169 ( } \phi 80 \text { lacZDM15) bsdR } 17 \text { recA1 end A1 gyr A96 thi-1 } \\
\text { relA1 }\end{array}$ & Hanahan (1983) \\
\hline \multicolumn{3}{|l|}{ Plasmids } \\
\hline pRK2013 & $\begin{array}{l}\text { ColE1 replicon with } \mathrm{RK} 2 \text { tra genes, helper plasmid used for } \\
\text { mobilizing IncP and IncQ group plasmids, } \mathrm{Km}^{\mathrm{R}}\end{array}$ & Figurski \& Helinski (1979) \\
\hline Bluescript II SK- & $\begin{array}{l}\text { Phagemid, } \mathrm{f} 1(-) \text { origin of replication, ColE1 replicon, SK } \\
\text { polylinker, } 2.96 \mathrm{~kb} \text {, standard cloning vector, } \mathrm{Amp}^{\mathrm{R}}\end{array}$ & Stratagene \\
\hline PMP220 & $\begin{array}{l}\text { IncP broad-host-range mobilizable promoter probe vector } \\
\text { employing } E \text {. coli lac } Z \text { as reporter gene, } 10 \cdot 5 \mathrm{~kb}, T c^{\mathrm{R}}\end{array}$ & Spaink et al. (1987) \\
\hline pAR36A & $\begin{array}{l}\text { glnIIp-lac Z promoter probe cloned in pMP220, promoter derived } \\
\text { from } R \text {. leguminosarum bv. viciae strain LPR } 105, \mathrm{Tc}^{\mathrm{R}}\end{array}$ & Patriarca et al. (1992) \\
\hline $\mathrm{PJQ} 200 \mathrm{KS}$ & Narrow-host-range (p15A ori) mab sacB, $5.4 \mathrm{~kb}, \mathrm{Gm}^{\mathrm{R}}$ & Quandt \& Hynes (1993) \\
\hline $\mathrm{pHP} 45 \Omega$ & $\begin{array}{l}4.3 \mathrm{~kb} \text { plasmid containing } 2.0 \mathrm{~kb} \Omega \text { interposon encoding the gene } \\
\text { for } \mathrm{Sp}^{\mathrm{R}} \text { with transcription and translation termination signals at } \\
\text { both ends, } \mathrm{Amp}^{\mathrm{R}} \mathrm{Sp}^{\mathrm{R}}\end{array}$ & Prentki \& Krisch (1984) \\
\hline $\mathrm{pIJ} 1848$ & $\begin{array}{l}\text { Cosmid containing dct } A-B-D \text { from } R \text {. leguminosarum strain } 8002 \text {, } \\
T c^{\mathrm{R}}\end{array}$ & Mavridou et al. (1995) \\
\hline $\mathrm{pRU} 47$ & $\begin{array}{l}10.4 \mathrm{~kb} \text { HindIII fragment containing } d a t \text { region from plJ1848 in } \\
\text { Bluescript II SK-, Amp }\end{array}$ & Poole et al. (1994) \\
\hline pRU103 & $\begin{array}{l}0.9 \mathrm{~kb} \text { dot } A-B \text { intergenic tegion on EcoRI fragment from } \mathrm{pRU} 16 \text { in } \\
\text { PMP220, dct } A p-l a c Z, \mathrm{Tc}^{\mathrm{R}}\end{array}$ & This work \\
\hline pRU150 & $\begin{array}{l}6.1 \mathrm{~kb} \text { ClaI fragment from pRU47 religated to Bluescript II SK-, } \\
\text { contains complete dot region, Amp }\end{array}$ & This work \\
\hline pRU151 & $\begin{array}{l}6.1 \mathrm{~kb} X b a \mathrm{I} / \mathrm{HindIII} \text { fragment from } \mathrm{pRU} 150, \text { filled in and religated, } \\
\mathrm{Amp}^{\mathrm{K}}\end{array}$ & This work \\
\hline pRU168 & $\begin{array}{l}3.6 \mathrm{~kb} \text { Notl } / A p a \mathrm{I} \text { insert from } \mathrm{pRU} 157 \text { in } \mathrm{pJQ} 200 \mathrm{KS}, \Delta d c t D-\Omega \\
\text { suicide vector, } \mathrm{Gm}^{\mathrm{R}} \mathrm{Sp}^{\mathrm{R}}\end{array}$ & This work \\
\hline pRU193 & $\begin{array}{l}5.5 \mathrm{~kb} N o t \mathrm{l} / A p a \mathrm{I} \text { insert from } \mathrm{pRU} 401 \text { in } \mathrm{pJQ} 200 \mathrm{KS}, \triangle d c t A B D-\Omega \\
\text { suicide vector, } \mathrm{Gm}^{\mathrm{R}} \mathrm{Sp}^{\mathrm{R}}\end{array}$ & This work \\
\hline pRU294 & $\begin{array}{l}6.7 \mathrm{~kb} \text { NotI/ApaI insert from } \mathrm{pRU} 323 \text { in } \mathrm{pJQ} 200 \mathrm{KS}, \triangle \operatorname{dct} B D-\Omega \\
\text { suicide vector, } \mathrm{Gm}^{\mathrm{R}} \mathrm{Sp}^{\mathrm{R}}\end{array}$ & This work \\
\hline pRU324 & $\begin{array}{l}8.2 \mathrm{~kb} N o t \mathrm{I} / A p a \mathrm{I} \text { insert from } \mathrm{pRU} 321 \text { in } \mathrm{pJQ} 200 \mathrm{KS}, \operatorname{dct} A-\Omega \\
\text { suicide vector, } \mathrm{Gm}^{\mathrm{R}} \mathrm{Sp}^{\mathrm{R}}\end{array}$ & This work \\
\hline pRU325 & $\begin{array}{l}8.2 \mathrm{~kb} \text { Not } \mathrm{L} / A p a \mathrm{I} \text { insert from } \mathrm{pRU} 322 \text { in } \mathrm{pJQ} 200 \mathrm{KS}, \text { detB- } \Omega \\
\text { suicide vector, } \mathrm{Gm}^{\mathrm{R}} \mathrm{Sp}^{\mathrm{R}}\end{array}$ & This work \\
\hline pRU3001 & Cosmid from strain 3841 containing dct region, $T c^{R}$ & Poole et al. (1994) \\
\hline pRU3024 & Cosmid from strain 3841 containing the $a a p$ operon, $\Gamma^{\mathrm{R}}$ & Walshaw \& Poole (1996) \\
\hline pRU3028 & Cosmid $\mathrm{pRU} 3024$ containing aap J::Tn 5-lac $Z, \mathrm{Tc}^{\mathrm{R}}$ & Walshaw \& Poole (1996) \\
\hline
\end{tabular}

insert DNA on the $d c t B$ side and $0.9 \mathrm{~kb}$ on the $d t D$ side. Plasmid pRL294 contains a $1.4 \mathrm{~kb}$ deletion from the EcoRI site in $\operatorname{dct} B$ to the $S m a \mathrm{I}$ site of $d c t D$; the EcoRI overhang was filled using the
Klenow fragment and the $\Omega$ interposon was blunt-end-cloned into this site. This deleted up to the first $164 \mathrm{bp}$ of $d t t D$. The $\Omega$ interposon is flanked by $3.0 \mathrm{~kb}$ of DNA homologous to strain 
3841 on the $\operatorname{dct} A$ side and $1.7 \mathrm{~kb}$ on the $\operatorname{dct} D$ side. Plasmid pRU193 contains a deletion spanning the $d t t$ region from the BamHI site in $\operatorname{dct} A$ (379 bp from the $5^{\prime}$ end) to the EcoRV site in $d t t D$ (164 bp from the $5^{\prime}$ end), into which the $\Omega$ interposon was cloned. The $\Omega$ interposon is flanked by $1.8 \mathrm{~kb}$ on the $d t . A$ side and $1.7 \mathrm{~kb}$ on the $\operatorname{dat} D$ side. All of these clones in pBluescript II SK - were transferred to pJQ200KS using appropriate restriction sites in the polylinker.

Plasmids containing $d t t$ mutations were triparentally conjugated into strain 3841 and the whole conjugation mix plated on $T Y$ containing $5 \%(\mathrm{w} / \mathrm{v})$ sucrose, streptomycin and spectinomycin. This allowed direct selection for colonies containing double recombination events which appeared after 3-4 dincubation at $25^{\circ} \mathrm{C}$. These were shown to be gentamicin-sensitive, indicating loss of the plasmid and were unable to grow on succinate as the sole carbon source. Finally, isolated genomic DNA from each mutant was digested with HindIII and Southern-blotted with $\operatorname{dit} A-, d c t B$ - and $d c t D$-specific plasmid probes, to confirm the expected gene replacements. The final strains produced are shown in Table 1.

\section{RESULTS}

\section{The role of the Dct system in negatively regulating the Aap}

Unlike R. meliloti, cells of R. leguminosarum strain 3841 are unable to grow on aspartate as a sole source of carbon and nitrogen. The only exception to this is when mutation and selection results in the acquisition of aspartase activity in some strains of R. leguminosarum, such as WU235 (Poole et al., 1984). However, aspartate is capable of supporting growth of $R$. leguminosarum strain 3841 as a nitrogen source. The mean generation times were $189 \mathrm{~min}$ and $264 \mathrm{~min}$ on malate/ammonia and on malate/aspartate minimal medium, respectively. Strain 3841 grown on glucose/ammonia had a mean generation time of $270 \mathrm{~min}$. This was increased to $660 \mathrm{~min}$ during growth on glucose/aspartate. It is particularly unusual that while aspartate causes a moderate inhibition of growth on dicarboxylates, it is profoundly inhibitory when glucose is the carbon source. Given the possible importance of aspartate in regulation of carbon metabolism in the nodule, we investigated how it affects nitrogen-regulated operons.

In $R$. leguminosarum strain 3841 aspartate uptake was low in cells grown on glucose/ammonia which is a nitrogenexcess condition (Table 2), while it was derepressed fourfold in cells grown on glucose/glutamate. This is presumably due to glutamate being a poor nitrogen source relative to ammonia, effectively causing nitrogenlimitation (Poole et al., 1985, 1987). However, when cells were grown on glucose/aspartate, which was also expected to be a poor nitrogen source, aspartate uptake was even lower than that measured in cells grown on glucose/ammonia (Table 2). In all these uptake experiments the substrate was at a final concentration of $25 \mu \mathrm{M}$, a concentration at which over $80 \%$ of aspartate and glutamate and $55 \%$ of alanine transport are lost in aap mutants (Walshaw \& Poole, 1996). It is therefore possible to ascribe the effect of aspartate in the growth medium on amino acid transport specifically to the Aap.
Uptake of aspartate via the Aap in $R$. leguminosarum strain 3841 was also measured in cells grown on succinate in conjunction with ammonia, aspartate or glutamate. The rate of aspartate uptake by the Aap was low in cells grown on succinate/ammonia but high in cells grown on succinate/aspartate or succinate/glutamate (Table 2). The high rate of transport measured in succinate/aspartateversus glucose/aspartate-grown cells suggests that the effect of aspartate is alleviated by succinate. This inhibitory/repressive effect of aspartate on the uptake of amino acids by the Aap was seen for all tested amino acids, not just aspartate itself. For example, cells of strain 3841 grown on glucose/ammonia compared to glucose/ aspartate showed glutamate and alanine uptake rates reduced by $52 \%$ and $47 \%$, respectively, by the presence of aspartate in the growth medium. This is consistent with the broad specificity of the Aap for L-amino acids.

Since succinate prevents the aspartate-dependent reduction in transport by the Aap, the Dct system might be involved. Therefore, the ability of aspartate to cause this effect was examined in a series of $R$. leguminosarum dct mutants. Aspartate uptake in strains RL727 (dct $A)$, RU730 ( $d c t B), \quad R U 711(\Delta d c t D), \quad R U 865(\Delta d c t B D)$ and RU714 ( $\triangle d c t A B D$ ) was measured after growth on glucose as the carbon source and ammonia, aspartate or glutamate as the nitrogen source (Table 2). Strains mutated in the dot genes are unable to grow on succinate as a sole carbon source so it was not possible to measure aspartate uptake under such conditions. Aspartate uptake was also measured as a control in strain 3841 on the above substrates and also with succinate as a carbon source.

Cells of all $d c t$ strains grown on glucose/ammonia showed normal repressed levels of uptake by the Aap due to the nitrogen-excess status of the culture. As in strain 3841, uptake of aspartate by the Aap was derepressed in all $d c t$ strains after growth on glucose/glutamate indicating that they still respond to a poor nitrogen source. However, cells of all dit strains grown on glucose/aspartate no longer displayed inhibition/repression of aspartate uptake by the Aap. Thus mutation of any component of the Dct system alleviates the inhibition/repression of the Aap evident in cells grown on glucose/aspartate.

\section{Regulation of transcription from the aapJ and $g / n / l$ promoters $(g / n / / p)$ in response to aspartate}

To investigate whether the low rate of uptake in $R$. leguminosarum strain 3841 grown on glucose/aspartate is due to transcriptional repression of the aap, a $\operatorname{Tn} 5-l_{a c} Z$ fusion to aapJ ( $\operatorname{Tn} 5$-lacZ inserted at base 1176 of the aap, EMBL X82596) was used to measure transcription of the operon. When strain 3841 containing pRU3028 (pRU3024 aap J:: Tn 5-lacZ) was grown on glucose/ammonia it had a $\beta$-galactosidase activity of $3325 \pm 279 \mathrm{nmol} \mathrm{min}^{-1}$ (mg protein $)^{-1} \pm$ sem. After growth on glucose/aspartate the

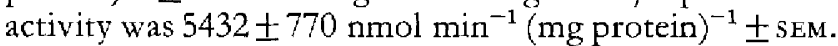
The modest increase after growth on the poor nitrogen source aspartate versus the rich nitrogen source ammonia, shows that the reduction in amino acid transport after growth on glucose/aspartate does not occur at the 
Table 2. Aspartate transport in R. leguminosarum strain 3841 and various dct mutants

Rates of aspartate transport (substrate concentration $25 \mu \mathrm{M}$ ) are given in nmol $\mathrm{min}^{-1}$ ( $\mathrm{mg}$ protein $)^{-1} \pm$ SEM and are the means of at least three independent cultures.

\begin{tabular}{|c|c|c|c|c|c|c|c|}
\hline \multirow[t]{2}{*}{ Strain } & \multirow[t]{2}{*}{ Genotype } & \multicolumn{6}{|c|}{ Growth conditions* } \\
\hline & & $\mathrm{G} / \mathrm{N}$ & G/Asp & G/Glu & $\mathrm{S} / \mathrm{N}$ & S/Asp & S/Glu \\
\hline 3841 & Wild-type & $2 \cdot 8 \pm 0 \cdot 4$ & $1 \cdot 4 \pm 0.2$ & $11 \cdot 8 \pm 0 \cdot 4$ & $2 \cdot 1 \pm 0 \cdot 4$ & $15 \cdot 2 \pm 0 \cdot 3$ & $10 \cdot 1 \pm 1 \cdot 5$ \\
\hline RU727 & $\operatorname{dct} A:: \Omega$ & $3 \cdot 6 \pm 0 \cdot 1$ & $8 \cdot 2 \pm 0 \cdot 4$ & $9 \cdot 1 \pm 0 \cdot 4$ & & & \\
\hline RU730 & $\operatorname{dct} B:: \Omega$ & $2 \cdot 6 \pm 0.5$ & $7.9 \pm 1.9$ & $11 \cdot 2 \pm 0 \cdot 6$ & & & \\
\hline RU711 & $\operatorname{dct} D:: \Omega$ & $4 \cdot 4 \pm 0 \cdot 9$ & $11 \cdot 6 \pm 0 \cdot 4$ & $11 \cdot 6 \pm 1 \cdot 0$ & & & \\
\hline RL865 & $\Delta d t B D:: \Omega$ & $3 \cdot 3 \pm 0 \cdot 7$ & $17 \cdot 6 \pm 0.9$ & $18 \cdot 1 \pm 0.8$ & & & \\
\hline RU714 & $\triangle d c t A B D:: \Omega$ & $3 \cdot 9 \pm 1 \cdot 2$ & $15 \cdot 0 \pm 4 \cdot 0$ & $11 \cdot 2 \pm 1 \cdot 0$ & & & \\
\hline
\end{tabular}

* G, glucose; S, succinate; N, ammonia; Glu, glutamate; Asp, aspartate.

Table 3. $\beta$-Galactosidase activities in R. leguminosarum strains containing g/nllp and dctAp lacZ fusions

Results are shown as ONPG hydrolysed in $\mathrm{nmol} \mathrm{min}^{-1}$ (mg protein $)^{-1} \pm \mathrm{SEM}$ from at least three independent cultures.

\begin{tabular}{|c|c|c|c|c|c|c|c|c|c|c|c|}
\hline \multirow[t]{2}{*}{ Strain } & \multirow[t]{2}{*}{ Genotype* } & \multicolumn{10}{|c|}{ Growth conditions } \\
\hline & & $\mathbf{G} / \mathbf{N}$ & G/Asp & G/Glu & $\mathbf{S} / \mathbf{N}$ & S/Asp & S/Glu & $\mathbf{G} / \mathrm{S} / \mathrm{N}$ & $\mathrm{G} / \mathrm{S} / \mathrm{Asp}$ & G/S/Glu & $\mathrm{G} / \mathrm{Asp} / \mathrm{N}$ \\
\hline RL622 & Wild-type & $288 \pm 26$ & $362 \pm 52$ & $1126 \pm 31$ & $474 \pm 100$ & $1582 \pm 157$ & $1400 \pm 80$ & $441 \pm 9$ & $1616 \pm 158$ & $1587 \pm 93$ & $349 \pm 39$ \\
\hline RL782 & $\operatorname{dct} A:: \Omega$ & $379 \pm 16$ & $1293 \pm 77$ & $1407 \pm 46$ & & & & $502 \pm 23$ & $1860 \pm 102$ & $1777 \pm 135$ & $445 \pm 16$ \\
\hline RU788 & $\operatorname{dct} B:: \Omega$ & $365 \pm 34$ & $1383 \pm 110$ & $1329 \pm 60$ & & & & $475 \pm 5$ & $1549 \pm 94$ & $1667 \pm 37$ & $466 \pm 13$ \\
\hline RL793 & $\operatorname{dct} D:: \Omega$ & $424 \pm 28$ & $1516 \pm 144$ & $1370 \pm 55$ & & & & $459 \pm 15$ & $1453 \pm 111$ & $1481 \pm 149$ & $445 \pm 26$ \\
\hline RL948 & $\Delta d c t B D:: \Omega$ & $419 \pm 4$ & $1234 \pm 94$ & $1293 \pm 82$ & & & & $363 \pm 10$ & $1603 \pm 46$ & $1580 \pm 31$ & $429 \pm 11$ \\
\hline RL'802 & $\triangle \operatorname{dat} A B D:: \Omega$ & $403 \pm 46$ & $1252 \pm 51$ & $1286 \pm 36$ & & & & $484 \pm 49$ & $1955 \pm 50$ & $1716 \pm 145$ & $5458 \pm 37$ \\
\hline Ru364 & Wild-type & $266 \pm 61$ & $1533 \pm 356$ & & $2067 \pm 267$ & $3433 \pm 101$ & & & & & \\
\hline
\end{tabular}

* All strains contain $g / n I I::$ lac $Z$ fusions except RU364 which contains a $\operatorname{dct} A::$ lac $Z$ fusion.

† Abbreviations are as for Table 2.

transcriptional level. Strain 3841 containing the parent cosmid had no detectable $\beta$-galactosidase activity under these growth conditions.

To determine whether aspartate specifically reduces transport by the Aap, other nitrogen-regulated genes were investigated. One such gene in $R$. loguminosarum, whose transcription is $\mathrm{NtrC}$-dependent, is glnII (Patriarca et al., 1992; Morett et al., 1985). Transcription from the $g I n I I p$ was therefore assayed using the glnII-lac $Z$ fusion contained on pAR36A (Patriarca et al,, 1992). This was conjugated into strain 3841, generating strain RU622, which was grown under identical conditions as for amino acid transport and the activity of $\beta$-galactosidase measured.

Strain RU622 displayed a similar regulatory pattern for transcription from the $g h I I p$ as seen for total amino acid uptake by the Aap (Table 3). Transcription from the glnIIp was repressed on glucose/ammonia and succinate/ ammonia, which are nitrogen-excess conditions. When strain RL622 was grown on glucose/glutamate, succi- nate/aspartate or succinate/glutamate which are nitrogen-poor conditions, transcription from the glnIIp was derepressed indicating that it responds to the nitrogen status of the cell. However, when strain 3841 was grown on glucose/aspartate, repression of transcription from the $g \ln I p$ was evident. The level of transcription was similar to that of cells grown on glucose/ammonia. Expression from the glnIIp in the wild-type therefore shows a comparable pattern of regulation to that for the inhibition of uptake of amino acids by the Aap. Clearly though there must be differences in the mechanism of negative regulation of aap and $g / n I I$ since only the latter involves transcriptional repression. Once again, succinate appeared to be capable of alleviating the repression of the $g \ln I I p$ caused by aspartate.

Cells were next grown on combinations of substrates to further investigate how succinate alleviates the aspartatedependent repression. When strain RU622 was grown on glucose/succinate/aspartate, transcription from the glnIIp was derepressed indicating that succinate relieves the repression and that it is not caused by glucose (Table 3 ). 
All other combinations of growth substrates gave results consistent with the nitrogen status of the medium.

\section{Regulation of transcription from the glnllp in various dct strains in response to the nitrogen source}

Mutation of any component of the Det system alleviated the aspartate-dependent inhibition of uptake of amino acids by the Aap after growth on glucose/aspartate. Since the pattern of repression of the ginIIp in cells grown on glucose/aspartate appeared to match the inhibition of uptake by the Aap, the effect of mutations in the $d c t$ system on transcription of the glnIIp were examined.

Plasmid pAR36A (glnII $p$ reporter probe) was conjugated into strains RU727 (dct $A$ ), RU730 (dctB), RU711 ( $\Delta d t c D)$, RU865 ( $\triangle d c t B D$ ) and RU714 ( $\triangle \operatorname{dct} A B D)$ generating respectively strains RU782, RU788, RU793, RU948 and RU802. These strains were grown under identical conditions as for measurement of amino acid uptake; however because they are unable to use succinate as a sole carbon source it was supplied in conjunction with glucose.

When grown under nitrogen-excess conditions (c.g. glucose/ammonia) all of the $d c t$ strains showed repressed levels of transcription from the $g \ln I T$, while after growth under nitrogen-poor conditions (e.g. glucose/glutamate), transcription from the ginII $p$ was derepressed (Table 3). When grown on glucose/aspartate, transcription from the ginIIp was derepressed, which is comparable to the result obtained for uptake of amino acids by the Aap in $d c t$ strains. This indicates that aspartate transport mediated by the Dct system leads to negative regulation of both uptake by the Aap and glnII transcription.

\section{Relief of the aspartate-dependent repression by 2 - methylsuccinate}

2-Methylsuccinate is an analogue of succinate which does not support growth of $\mathrm{R}$. leguminosarum biovar viciae strain 3841 when supplied as the carbon source, not does it induce the dtt system. However, it can compete with succinate for transport, indicating it must bind to and is probably transported by DctA (Glenn et al., 1980). As succinate is capable of alleviating the repression effect evident in cells grown on glucose/aspartate, we decided to investigate if 2-methylsuccinate could function in a similat fashion.

Transcription from the glnII $p$ was measured in cells grown on glucose/aspartate (repressive conditions) with different amounts of 2-methylsuccinate added. In strain RU622, transcription from the glnII $p$ was derepressed in the presence of 5 and $10 \mathrm{mM} 2$-methylsuccinate, but was repressed in the presence of $0.5 \mathrm{mM} 2$-methylsuccinate (Fig. 1). This indicates that 2-methylsuccinate alleviates the repression in a concentration-dependent fashion. This derepressed level of transctiption was in contrast to the control (strain RU622 grown on glucose/aspartate alone) and was comparable to the levels of transcription observed in the wild-type (strain RU622) grown on glucose/

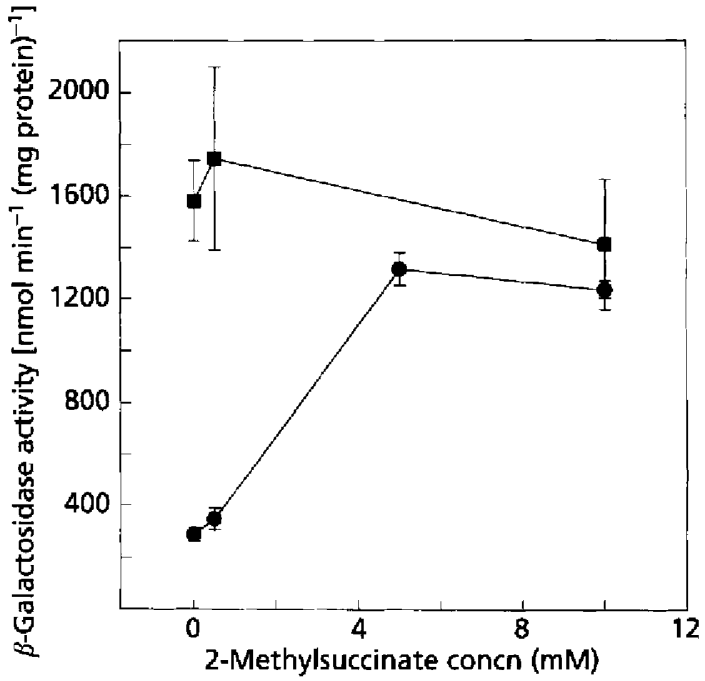

Fig. 1. Effect of 2-methylsuccinate in the growth medium on the activity of a g/nll-lacZ fusion in $R$. leguminosarum strain 3841. Cultures were grown on glucose/aspartate (C) or succinate/aspartate ( $\boldsymbol{\square}$ ) with 2-methylsuccinate at the indicated concentrations. Values shown are the means of three independent cultures \pm SEM.

glutamate (nitrogen-poor conditions). The effect of 2 methylsuccinate on transcription from the $g$ inII $p$ was also investigated in cells grown on succinate/aspartate (Fig. 1). Under these conditions it had no effect on transcription, which was always derepressed.

Uptake of aspartate by the Aap in strain 3841 was also measured in cells grown on glucose/aspartate in conjunction with $10 \mathrm{mM}$ 2-methylsuccinate. The level of transport was high $\left[11.0 \pm 2.0 \mathrm{nmol} \mathrm{min}{ }^{-1}\right.$ (mg protein $)^{-1} \pm$ SEM], in contrast to the wild-type grown on glucose/aspartate alone $\left[1.4 \pm 2.0 \mathrm{nmol} \mathrm{min}{ }^{-1}\right.$ (mg protein $)^{-1} \pm$ SEM], and was similar to that observed on glucose/glutamate (nitrogen-poor conditions).

Thus, 2-methylsuccinate is capable of alleviating the inhibition of uptake of amino acids by the Aap and transcription from the glnIIp evident in cells grown on glucose/aspartate. This indicates that metabolism of succinate is not required for relief of the aspartatedependent inhibition/repression. Succinate and 2-methylsuccinate presumably accomplish this by inhibiting binding of aspartate to DctA, hence lowering its intra-cellular accumulation.

\section{Kinetics of aspartate transport in strain $\mathbf{3 8 4 1}$}

Since these data show that aspartate transport mediated by the Dct system causes a severe repression or inhibition of nitrogen-regulated operons, the kinetics of the Det system for succinate uptake and inhibition by aspartate were determined. The apparent $K_{\mathrm{m}}$ for succinate uptake via the Dct system by strain 3841 was determined in cells grown on succinate/ammonia and was $5 \mu \mathrm{M}$ with an apparent 




Fig. 2. Inhibition of succinate uptake by aspartate in $R$. leguminosarum strain 3841. Cultures were grown on succinate/ ammonia. Control (succinate alone); $\boldsymbol{a}$, succinate plus aspartate $(5 \mathrm{mM}) ; \boldsymbol{A}$, succinate plus aspartate $(20 \mathrm{mM})$. Values shown are the means of three independent cultures \pm SEM.

$V_{\max }$ of $64 \mathrm{nmol} \mathrm{min}^{-1}$ (mg protein) $)^{-1}$ (Fig. 2). Aspartate is a competitive inhibitor of the Dct system with an apparent $K_{\mathrm{i}}$ of $5 \mathrm{mM}$, demonstrating it has a low affinity for binding. This indicates that at equimolar concentrations succinate would largely prevent binding of aspartate to the Dct system.

\section{Expression level of DctA}

Aspartate is a very efficient inducer of the $d c t$ system and the Dct-mediated effect of aspartate might result from overexpression of the transport protein relative to that which occurs after induction by succinate (Watson $e t a l$, 1993; Poole et al., 1994). This was investigated by conjugating the $\operatorname{det} A-$ lac $Z$ fusion contained on pRU103 into $R$. leguminosarum strain 3841, generating strain RU364. The induction caused by aspartate $(10 \mathrm{mM})$ was $5 \cdot 8$-fold, while that by succinate $(10 \mathrm{mM})$ was 7.8 -fold (Table 3). Furthermore, succinate and aspartate together, both at $10 \mathrm{mM}$, caused an induction of 13-fold. Clearly, aspartate is not a better inducer than succinate and the inclusion of both compounds in the growth medium, which prevents the aspartate-dependent repression of $g l n I I$, increased the induction of $\operatorname{dct} A$ further.

\section{DISCUSSION}

It is evident that transport by the Aap is decreased when the wild-type strain of $R$. leguminosarum is grown in the presence of aspartate and a carbon source such as glucose. This is not caused by repression of transcription suggesting the effect results from inhibition of uptake by the Aap. However, transcription from the glnIIp was decreased by the growth on glucose/aspartate. Both effects can be relieved in two ways; firstly by the inclusion of succinate or a non-metabolizable analogue of it in the growth medium, and secondly by mutation of any component of the Det system.

A number of transposon mutations in the dat system have been found to have complex regulatory effects on other operons inciuding nif and nod genes (Mavridou et al., 1995; Birkenhead et al., 1990). These have usually been found to map to $\operatorname{det} B$ and imply that disturbance of the balance between components of the dot system causes improper heterologous regulation of other operons. Given that DctD is a transcriptional activator that is closely related to $\mathrm{NtrC}$ and $\mathrm{NifA}$, it is possible that either improper expression or changes in its phosphorylation state may affect heterologous operons. In $\mathrm{R}$. meliloti, aspartate is a very efficient inducer of the dct system with growth on aspartate inducing higher rates of aspartate transport than growth on succinate or malate (Watson et al., 1993). This suggests that in $R$. leguminosarum strain 3841 , aspartate might cause greater induction of $\operatorname{det} A$ than substrates such as succinate, leading to improper crosstalk with other operons. By using a lac $Z$ fusion to $\operatorname{dct} A$, it was shown firstly, that aspartate does not lead to higher induction of $d c t A$ than that caused by succinate (Table 3 ), and secondly that the inclusion of succinate and aspartate together in the growth medium leads to the highest levels of $\operatorname{dct} A$ induction measured, although this combination of growth substrates prevents the aspartate-dependent repression of $g l n I I$ and inhibition of uptake by the Aap.

$A$ common factor linking $\operatorname{dct} A, \operatorname{dct} B$ and $\operatorname{dct} D$ strains is that they all lack DctA, implying that it is the carrier protein itself that mediates aspartate repression. It is unlikely that the effect is caused by improper phosphorylation of DctB of DctD since $\operatorname{dct} A$ strains, which escape the aspartate-dependent repression, are still capable of very high rates of phosphorylation (Yarosh et al., 1989; Jording et al., 1992). The requirement for Dct $A$ implies that the transport of aspartate by the permease could lead to high levels of intracellular aspartate which might cause inhibition of operons such as aapJQMP and repression of others such as $g$ lnII. To investigate this, the kinetics of succinate uptake were measured in the wild-type. The $d c t$ system is induced by the presence of dicarboxylates including aspartate and succinate, and has an apparent $K_{\mathrm{m}}$ for succinate uptake of $5 \mu \mathrm{M}$, with an apparent $K_{\mathrm{i}}$ for inhibition of succinate uptake by aspartate of $5 \mathrm{mM}$. Since the expression of DctA is probably not subject to nitrogen-mediated regulation by the Ntr system, induction of $\operatorname{dct} A$ by aspartate has the potential to lead to the unregulated accumulation of intracellular aspartate. Unregulated accumulation of aspartate via $\operatorname{Dct} A$ would lead to it, and subsequently metabolites derived from it, having a high intracellular concentration, which might repress transcription of some nitrogen-regulated operons such as glnII and inhibit the products of others such as the Aap.

High rates of amino acid uptake by the Aap and transcription of $g / n I I$ were evident when either succinate or 2-methylsuccinate was present in the growth medium in conjunction with aspartate. Given the relative affinities of succinate and aspartate for $\operatorname{Dct} A$, when present in equal 
concentrations, succinate would essentially block transport of aspartate by DctA and prevent the build-up of its intracellular concentration. 2-Methylsuccinate might operate in a similar fashion to succinate in out-competing aspartate for transport via DctA.

In a strain mutated in any component of the $d c t$ operon, the DctA permease would either not be transcribed or functional and the levels of intracellular aspartate would not be augmented. As a consequence, dct strains grown on glucose/aspartate would have moderate levels of inttacellular aspartate allowing both high rates of transport by the Aap and derepression of glnII.

Nitrogen levels in $R$. leguminosarum are thought to be sensed by a similar mechanism to that operating in $E$. coli, where the ratio of 2-oxoglutarate to glutamine is sensed by the uridylyltransferase/uridylylremoving enzyme, resulting in changes in the uridylylation state of $\mathrm{P}_{\Pi}$. In turn, $\mathrm{P}_{\Pi}$ alters the ability of NtrB to act as a kinase/phosphatase on NtrC. During nitrogen-limitation, the ratio of 2 oxoglutarate to glutamine is high, resulting in an increased level of phosphorylated NtrC, which activates the transcription of appropriate nitrogen-regulated operons (Amar et al., 1994; Patriarca et al., 1993). For example, R. leguminosarum biovar viciae grown under nitrogen limitation is derepressed for amino acid transport by the Aap and transcription of $g \ln I I$ (Poole et al., 1985; Patriarca $e t$ al., 1992).

Cellular glutamine, which is synthesized directly from glutamate by glutamine synthetase, is critical to nitrogensensing. Aspartate is readily converted to glutamate by aspartate aminotransferase and this increase in glutamate could lead to an increase in the intracellular concentration of glutamine, assuming glutamate is the limiting substrate for glutamine synthetase. Therefore, high levels of aspartate could result in a build-up of glutamine, which would increase the glutamine:2-oxoglutarate ratio indicative of nitrogen excess. As a consequence, this could lead to repression of Ntr-regulated operons such as ginII. This model may be rather simplistic though since the Aap appears to be inhibited rather than repressed by the presence of aspartate in the growth medium. Such a model implies that intracellular glutamate levels may be important. However, growth of cells of strain 3841 on glucose/glutamate with glutamate at concentrations from 10 to $50 \mathrm{mM}$ did not cause inhibition of the Aap. Furthermore, strain 3841 can be grown on glutamate as the sole carbon and nitrogen source without inhibition of the Aap. Indeed, mutation of aap genes prevents growth onglutamateasthesolecarbonsource(Walshaw \& Poole,1996). However, these results can be misleading because it is the steady-state intracellular concentration of glutamate that is important. Growth on high external concentrations of amino acids may not lead to highly elevated intracellular concentrations if transport and metabolism are tightly tegulated. Aspartate probably only leads to an elevated intracellulat amino acid pool in strain 3841 because the Dct system is unlikely to be regulated by this pool. Regulation of amino acid transport via the Aap by inhibition, tather than by repression, may be a response to the size of the amino acid pool.
Alternatively, aspartate or a metabolic product of it could be important and changes in its intracellular concentration could signal directly to the Ntr or to other systems in the cell which are regulated by amino acid availability. For example, leucine-responsive protein is clearly involved in the regulation of amino acid uptake by a number of transport systems (Haney et al., 1992; Haney \& Oxender, 1992). However, the complexity of the possible metabolic fates for aspartate prevent any simple conclusion.

Aspartate metabolism is clearly very important to nitrogen signalling in R. leguminosarum. It is therefore interesting that aspartate aminotransferase mutants of $R$. meliloti are unable to fix nitrogen on alfalfa plants (Rastogi \& Watson, 1991; Watson \& Rastogi, 1993). The data in this work imply that minor perturbations in the intracellular concentration of aspartate may have quite dramatic effects on nitrogen signalling, metabolism and growth generally. This alone may explain the inability of bacteroids mutated in aspartate aminotransferase to fix nitrogen, without the need to postulate that bacteroid metabolism involves a complex malate/aspartate shuttle. However, aspartate metabolism is very different between R. meliloti and R. leguminosarum, with the former, but not the latter, able to grow on aspartate as a sole carbon and nitrogen source. $R$. meliloti catabolizes aspartate via aspartate aminotransferase, leading to the synthesis of glutamate. If the subsequent breakdown of glutamate via glutamate dehydrogenase and/or the $\gamma$-aminobutyric acid shunt, which are postulated to operate in $R$. meliloti (Fitzmaurice \& O'Gara, 1991, 1993), is sufficient to prevent amino acid accumulation via aspartate aminotransferase then there should be no disruption of nitrogen regulation. Aspartate aminotransferase mutations will of course alter this balance. It has recently been shown in Rhizobium etli that the enzyme aspartase is normally induced by asparagine, but not aspartate, explaining its ability to grow on the former but not the latter as a carbon source (Huerta-Zepeda et al., 1996). In R. leguminosarum only strains such as WU235, which have acquired a mutation enabling the constitutive expression of aspartase activity, can grow on aspartate as the sole carbon source (Poole et al., 1984). Aspartase splits aspartate directly to fumarate and ammonia, preventing build-up of aspartate and glutamate in the cell. Since transport of aspartate is adequate to support growth in strains such as 3841 and WU235, the inability to grow in the absence of aspartase may result from imbalances in the intracellulat amino acid pool. The key point is that all steps in the transport and metabolism of aspartate must operate co-ordinately and at sufficient rates to ptevent the build-up of inhibitory concentrations of metabolic intermediates. Failure to do this may prevent growth on aspartate as a carbon source or nitrogen fixation by bacteroids.

\section{REFERENCES}

Amar, M., Patriarca, E. J., Manco, G., Bernard, P., Riccio, A., Lamberti, A., Defez, R. \& laccarino, M. (1994). Regulation of nitrogen metabolism is altered in a $g \ln B$ mutant strain of Rbizobium leguminosarum. Mol Micrabiol 11, 685-693.

Appels, M. A. \& Haaker, H. (1991). Glutamate oxaloacetate 
transaminase in pea root nodules-participation in a malate/ aspartate shuttle between plant and bacteroid. Plant Pbysiol 95, $740-747$.

Arwas, R., McKay, I. A., Rowney, F. R. P., Dilworth, M. J. \& Glenn, A. R. (1985). Properties of organic acid utilization mutants of Rbizobium leguminosarum strain 300. J Gen Microbiol 131, 2059-2066.

Beringer, J. E. (1974). R factor transfer in Rhiqobium leguminosarum. J Gen Microbiol 84, 188-198.

Birkenhead, K., Noonan, B., Reville, W. J., Boesten, B., Manian, S. S. \& Ogara, F. (1990). Carbon utilization and regulation of nitrogen-fixation genes in Rhizobium meliloti. Mol Plant-Microbe Interact 3, 167-173.

Brown, C. M. \& Dilworth, M. J. (1975). Ammonia assimilation by Rbizobium cultures and bacteroids. J Gen Microbiol 86, 39-48.

Driscoll, B. T. \& Finan, T. M. (1993). NAD'-dependent malic enzyme of Rhizobium meliloti is required for symbiotic nitrogen fixation. Mol Microbiol 7, 865-873.

Engelke, T., Jording, D., Kapp, D. \& Pühler, A. (1989). Identification and sequence analysis of the Rbirobium meliloti det $A$ gene encoding the $\mathrm{C}_{4}$-dicarboxylate carrier. J Bacteriol 171, 5551-5560.

Figurski, D. H. \& Helinski, D. R. (1979). Replication of an origincontaining derivative of plasmid RK2 dependent on a plasmid function provided in trans. Proc Natl Aad Sci US A 76, 1648-1652.

Finan, T. M., Wood, J. M. \& Jordan, D. C. (1983). Symbiotic properties of $\mathrm{C}_{4}$-dicarboxylic acid transport mutants of Rhizobium leguminosarum. J Bacteriol 154, 1403-1413.

Fitzmaurice, A. M. \& O'Gara, F. (1991). Glutamate catabolism in Rhizobium melitoti. Arch Microbiol 155, 422-427.

Fitzmaurice, A. M. \& O'Gara, F. (1993). A Rhizobium meliloti mutant, lacking a functional gamma-aminobutyrate (GABA) bypass, is defective in glutamate catabolism and symbiotic nitrogen fixation. FEMS Microbiol Lett 109, 195 -202.

Glenn, A. R. \& Dilworth, M. J. (1981). Oxidation of substratcs by isolated bacteroids and free-living cells of $\mathrm{R}$ hizobium leguminosarum 3841. J Gen Microbiol 126, 243-247.

Glenn, A. R., Poole, P. S. \& Hudman, J. F. (1980). Succinate uptake by free-living and bacteroid forms of Rhiqobium leguminosarum. J Gen Microbiol 119, 267-271.

Glenn, A. R., McKay, I. A., Arwas, R. \& Dilworth, M. J. (1984). Sugar metabolism and the symbiotic properties of carbohydrate mutants of Rbizobium leguminosarum. J Gen Microbiol 130, 239-245.

Hanahan, D. (1983). Studies on transformation of Escheribia coli with plasmids. $J$ Mol Biol 166, 557-580.

Haney, S. A. \& Oxender, D. L. (1992). Amino acid transport in bacteria. Int Rev Cytol 137A, 37-95.

Haney, S. A., Platko, J. V., Oxender, D. L. \& Calvo, J. M. (1992). Lrp, a leucine-responsive protein, regulates branched-chain amino acid transport genes in Escherichia coli. J Bacteriol 174, 108-115.

Huerta-Zepeda, A., Durán, S., Du Pont, G. \& Calderón, J. (1996). Asparagine degradation in Rhizobium etli. Microbiology 142, 1071 1076.

Jiang, J., Gu, B., Albright, L. M. \& Nixon, B. T. (1989). Conservation between coding and regulatory elements of Rbizobium meliloti and Rbizobium leguminosarum dat genes. J Bacteriol 171, 5244- 5253.

Johnston, A. W. B. \& Beringer, J. E. (1975). Identification of the Rhizobium strains in pea toot nodules using genetic markers. I Gen Microbiol 87, 343-350.

Jording, D., Sharma, P. K., Schmidt, R., Engelke, T., Uhde, C. \& Puhler, A. (1992). Regulatory aspects of the $C_{4}$-dicarboxylate transport in Rhiqobium meliloti-transcriptional activation and dependence on effective symbiosis. J Plant Physiol 141, 18-27.
Ledebur, H. \& Nixon, B. T. (1992). 'Tandem DctD-binding sites of the Rbizobium meliloti dct.A upstream activating sequence are essential for optimal function despite a 50 -fold to 100 -fold difference in affinity for DctD. Mol Microbiol 6, 3479-3492.

Ledebur, H., Gu, B., Sojda, J. I. \& Nixon, B. T. (1990). Rhizobium meliloti and Rbizobium leguminosarum dctD gene products bind to tandem sites in an activation sequence located upstream of sigma54dependent dot A promoters. J Bacteriol 172, 3888-3897.

Mavridou, A., Barny, M.-A., Poole, P., Plaskitt, K., Davies, A. E., Johnston, A. W. B. \& Downie, J. A. (1995). Rhizobium leguminosarum nodulation gene (nod) expression is lowered by an allele-specific mutation in the dicarboxylate transport gene detB. Microbiology 141, 103111.

Morett, E., Moreno, S. \& Espin, G. (1985). Impaired nitrogen fixation and glutamine synthesis in methionine sulfoximine sensitive (MST ${ }^{3}$ ) mutants of Rhizobium phaseoli. Mol Gen Genet 200, 229-234.

Patriarca, E. J., Chiurazzi, M., Manco, G., Riccio, A., Lamberti, A., Depaolis, A., Rossi, M., Defez, R. \& laccarino, M. (1992). Activation of the Rbizobium leguminosarum ginII gene by $\mathrm{NtrC}$ is dependent on upstream DNA sequences. Mol Gen Genet 234, 337-345.

Patriarca, E. J., Riccio, A., Tate, R., Cołonna-Romano, S., laccarino, M. \& Defez, R. (1993). The ntrBC genes of Rhizobium leguminosarum are part of a complex operon subject to negative regulation. Mol Microbiol 9, 569-577.

Poole, P. S., Dilworth, M. J. \& Glenn, A. R. (1984). Acquisition of aspartase activity in Rbizobium leguminosarum WU235. / Gen Microbiol 130, 881-886.

Poole, P. S., Franklin, M., Glenn, A. R. \& Dilworth, M. J. (1985). The transport of L-glutamate by Rhizobium leguminosarum involves a common amino acid carrier. J Gen Microbiol 131, 1441-1448.

Poole, P. S., Dilworth, M. J. \& Glenn, A. R. (1987). Ammonia is the preferted nitrogen source in several thizobia. J Gen Microbiol 133, 1707-1712.

Poole, P. S., Schofiejd, N. A., Reid, C. J., Drew, E. M. \& Walshaw, D. L. (1994). Identification of chromosomal genes located downstream of $d c t D$ that affect the requirement for calcium and the lipopolysaccharide layer of Rbizobium leguminosarum. Microbiology 140, 2797-2809.

Prentki, P. \& Krisch, H. M. (1984). In vitro insertional mutagenesis with a selectable DNA fragment. Gene 29, 303313.

Quandt, J. \& Hynes, M. F. (1993). Vcrsatile suicide vectors which allow direct selection for gene replacement in Gram-negative bacteria. Gene 127, 1521.

Rastogi, V. K. \& Watson, R. J. (1991). Aspartate aminotransferase activity is required for aspartate catabolism and symbiotic nitrogen fixation in Rhizobium meliloti. J Bacteriol 173, 2879-2887.

Ronson, C. W. (1988). Genetic regulation of $\mathrm{C}_{4}$-dicarboxylate transport in thizobia. In Nitrogen Fixation: Hundred Years After, pp. 547-551. Edited by H. Bothe, F. J. Bruijn \& W. E. Newton. New Yotk: Gustav Fischer.

Ronson, C. W. \& Astwood, P. M. (1985). Genes involved in the carbon metabolism of bacteroids. In Nitrogen Fixation Researb Progress, pp. 201-207. Edited by E. D. Evans, P. J. Bottomley \& W. E. Newton. Dordrecht: Martinus Nijhoff.

Ronson, C. W., Lyttleton, P. \& Robertson, J. G. (1981). C dicarboxylate transport mutants of Rhizobium trifolii form ineffective nodules on Trifolium repens. Proc Natl Acad Si USA 78, $4284-4288$.

Ronson, C. W., Astwood, P. M. \& Downie, J. A. (1984). Molecular cloning and genetic organization of $\mathrm{C}_{4}$-dicarboxylate transport genes from Rhizobium leguminosarum. J Bacteriol 160, 903-909.

Ronson, C. W., Astwood, P. M., Nixon, B. T. \& Ausubel, F. M. 
(1987). Deduced products of $\mathrm{C}_{4}$-dicarboxylate transport regulatory genes of Rbiqobium leguminosarum are homologous to nitrogen regulatory gene products. Nucleic Acids Res 15, 7921-7934.

Rosendahl, L., Dilworth, M. J. \& Glenn, A. R. (1992). Exchange of metabolites across the peribacteroid membrane in pea root nodules. J Plant Pbysiol 139, 635-638.

Salminen, S. O. \& Streeter, J. G. (1987). Involvement of glutamate in the respiratory metabolism of Bradyrbizobium japonicum bacteroids. J Bacteriol 169, 495-499.

Salminen, 5. O. \& Streeter, J. G. (1990). Factors contributing to the accumulation of glutamate in Bradyrbizobium japonicum bacteroids under microaerobic conditions. J Gen Microbiol 136, 2119-2126.

Salminen, S. O. \& Streeter, J. G. (1992). Labeling of carbon pools in Bradyrbizobium japonicum and Rbizobium leguminosarum bv. viciae bacteroids following incubation of intact nodules with ${ }^{14} \mathrm{CO}_{2}$. Plant Pbysiol 100, 597-604.

Sambrook, J., Fritsch, E. F. \& Maniatis, T. (1989). Molecular Cloning: a Laboratory Manual, 2nd edn. Cold Spring Harbor, NY: Cold Spring Harbor Laboratory.

Simon, R., Priefer, U. \& Puhler, A. (1983). A broad host-range mobilization system for in wivo genetic engineering: transposon mutagenesis of Gram-negative bacteria. Biotecbnology 1, 784-791.

Spaink, H.P., Okker, R. J. H., Wijffelman, C. A., Pees, E. \& Lugtenberg, B. J. J. (1987). Promoters in the nodulation region of the Rbizobium leguminosarum SYM plasmid PRL1JI. Plant Mol Biol9, 27-39.
Walshaw, D. L. \& Poole, P. S. (1996). The general L-amino acid permease of Rhizobium leguminosarum is an ABC uptake system that influences efflux of solutes Mol Microbiol (in press).

Wang, Y., Birkenhead, K., Boesten, B., Manian, S. \& O'Gara, F. (1989). Genetic analysis and regulation of the Rbizobium meliloti genes controlling $C_{4}$-dicarboxylic acid transport. Gene 85, 135-144.

Watson, R. J. (1990). Analysis of the $C_{4}$-dicarboxylate transport genes of Rbizobium meliloti: nucleotide sequence and deduced products of $\operatorname{dct} A, \operatorname{dctB}$ and $\operatorname{dct} D$. Mol Plant-Microbe Interact 3, 174-181.

Watson, R. J. \& Rastogi, V. K. (1993). Cloning and nucleotide sequencing of Rbizobium meliloti aminotransferase genes: an aspartate aminotransferase required for symbiotic nitrogen fixation is atypical. J Bacteriol 175, 1919-1928.

Watson, R. J., Rastogi, V. K. \& Chan, Y.-K. (1993). Aspartate transport in Rbizobium meliloti. J Gen Microbiol 139, 1315-1323.

Wood, W. B. (1966). Host specificity of DNA produced by Escberichia coli; bacterial mutations affecting the restriction and modification of DNA. J Mol Biol 16, 118-133.

Yarosh, O. K., Charles, T. C. \& Finan, T. M. (1989). Analysis of $C_{4}-$ dicarboxylate transport genes in Rhizobium meliloti. Mol Microbiol 3, 813-823.

Received 17 April 1996; accepted 26 April 1996. 